\title{
Diagnosis and referral flow in the single health system for climacteric women
}

\author{
(iD) Isabel Cristina Esposito Sorpreso $0^{1,2}$ \\ Francisco Winter dos Santos Figueiredo ${ }^{\mathbf{1 , 3}}$ \\ (iD) Adna Thaysa Marcial da Silva ${ }^{1}$ \\ (i) Juliana Zangirolami-Raimundo $\mathbf{1 , 2}$ \\ (iD) Bhárbara Karolline Rodrigues Silva ${ }^{3}$ \\ (iD) Fernando Adami ${ }^{3}$ \\ (iD) Lea Tami Suzuki Zuchelo ${ }^{1}$ \\ (iD) Edmund Chada Baracat ${ }^{1}$ \\ (i) José Maria Soares Júnior ${ }^{1}$ \\ (iD) Luiz Carlos de Abreu ${ }^{\mathbf{2 , 4}}$
}

\begin{abstract}
1. Disciplina de Ginecologia, Faculdade de Medicina FMUSP, Universidade de São Paulo, São Paulo, SP, Brasil 2. Laboratório de Delineamentos de Estudos e Escrita Científica, Centro Universitário Saúde ABC (FMABC), Santo André, SP, Brasil 3. Laboratório de Epidemiologia e Análise de Dados, Centro Universitário Saúde ABC (FMABC), Santo André, SP, Brasil 4. Escola Superior de Ciências da Santa Casa de Misericórdia de Vitória (Emescam), Vitória, ES Brasil
\end{abstract}

http://dx.doi.org/10.1590/1806-9282.66.8.1036

\section{SUMMARY}

OBJECTIVE: The association between gynecological diagnoses and their distribution across healthcare sectors benefits health promotion and the identification of topics for continued education of gynecological care. This study aimed to identify healthcare diagnoses and referral flow in climacteric women.

METHODS: This is a cross-sectional study conducted at the Women's Health Clinic of the University Hospital, University of São Paulo, with a reference to gynecology and training for Residents of Family and Community Medicine, between 2017 and 2018. The medical records of 242 women whose sociodemographic and clinical information, gynecological diagnoses, and distribution of healthcare services (primary, secondary, and tertiary) had been processed were collected. Statistical analysis included the chi-square test and odds ratio.

RESULTS: Smoking (OR = 2.27, 95\% CI 1.05-4.89; $p=0.035$ ) was associated with the referral of climacteric women to higher complexity services. Considering the distribution of non-oncological diagnoses in climacteric patients, the chance of women being referred to medium-and high-complexity health services presented a 2-fold increase in cases of breast diseases, a 2.35-fold increase in cases of noninflammatory disorders of the female genital tract, and a 3-fold increase in cases of inflammatory diseases of the pelvic organs.

CONCLUSION: Climacteric women aged over 55 years, postmenopausal women, and smoking women were most frequently referred to medium- and high-complexity outpatient surgery.

KEYWORDS: health services; gynecology; women's health; health care levels; health systems.

\section{INTRODUCTION}

Evaluating medium-complexity health services is important to ensure adequate care, guidance, and training for primary care network professionals and to maintain a balance between health care levels'. The evaluation process also allows for the analysis of procedures between providers and users (referencing) and

DATE OF SUBMISSION: 14-Jan-2020

DATE OF ACCEPTANCE: 22-Mar-2020

CORRESPONDING AUTHOR: Isabel Cristina Esposito Sorpreso

Address: Dr. Enéas de Carvalho Aguiar Avenue, n 255, 10. floor, room 10166 - 05403-000, São Paulo, SP, Brasil. Tel.: +55 (11) 26617621

E-mail: icesorpreso@usp.br 
of the final health situation (individual or collective) as a result of the complex between providers and consumers of healthcare interventions ${ }^{2}$.

The characterization of the assisted population at different levels of health services improves the quality of care. Consequently, topics relevant to women's health in interdisciplinary training in outpatient settings $^{3}$ are fundamental for the hierarchization of healthcare services, in which health promotion and treatment measures remain incipient. Some studies have reported that women who were referred to medium-complexity healthcare services had non-oncological gynecological diagnoses that were inadequately clinically managed in primary care $e^{4,5}$.

The climacteric period is the phase in a woman's life when prevention and promotion actions are expected to happen in primary care ${ }^{6,7}$. A projection study indicated that by 2020 , the demand for specific women's healthcare services will have grown by $6-10 \%$, in both developed and developing countries ${ }^{8}$. Studies associating gynecological diagnoses and their distribution at different complexities and healthcare service levels are rare, but they improve health promotion, continued and interdisciplinary medical education, and resource rationalization ${ }^{9-11}$. Thus, such studies significantly improve the various fields of action of a multidisciplinary team, with marked effects on public health, resulting in direct benefits to women's health ${ }^{3}$.

The objective of this study, which was conducted in a women's health assistance service that included a residency supervision in Family and Community Medicine, was to identify healthcare diagnoses and the referral flow of climacteric women.

\section{METHODS}

\section{Study design, location and period}

This study was conducted as a cross-sectional study at the Women's Health Outpatient Clinic, University Hospital of the University of São Paulo (ASM-HU/USP), from January 2017 to December 2018. The outpatient clinic is intended for gynecological care, teaching, learning, training, and supervision service for first-year Family and Community Medicine residents. It receives women with unsatisfactory or unexpected previous clinical management referred from basic health clinics to the medium-complexity reference outpatient clinic in the so-called Western Region Project (PRO, in the Portuguese acronym).

The PRO was an agreement between the University and the city government of São Paulo, Brasil, for the provision of assistance, education, and research; the development of joint activities with undergraduate Medicine, Speech Therapy, Physical Therapy, and Occupational Therapy courses, and for training graduate Family and Community Medicine, Psychiatry, Pediatrics, and General Medicine students. The basic health clinics in the PRO implement the Family Health Strategy of the Brazilian Unified Health System (SUS) in the western region of the city of São Paulo, which comprises the neighborhoods of Jardim Boa Vista, Butantã, Jardim d'Abril, Jardim São Jorge, Vila Dalva, Jardim Jaqueline, Vila Sônia, and Paulo VI.

\section{Study participants}

This is a secondary analysis of previously published data ${ }^{3}$ in which the medical records of 428 initial consultations were collected by convenience sampling. This study selected medical records of 242 women aged between 40 and 65 years.

\section{Data collection source}

The study used secondary data from the Medical Records Storage Service of the University Hospital of the University of São Paulo (SAME/HU/USP), and information from the first consultations of patients treated at the Women's Health Clinic was extracted.

\section{Data collection procedure}

All sociodemographic, clinical, and gynecological data, including information on the type of treatment, referral, and counter-referral, were collected using a standardized form and entered into a Microsoft Excel spreadsheet (.xls). Data were checked for consistency, and, in case of differences, the medical records were reread.

Sociodemographic variables considered were age, ethnicity, economic activity, and origin. The clinical variables included multiple morbidities (presence of two or more concomitant diseases), age at first sexual intercourse, age at menarche, age at last menstruation (age at menopause), sexual activity, parity, current smoking habit, and type of treatment (clinical or surgical).

The gynecological diagnoses were standardized according to the $10^{\text {th }}$ revision of the International Classification of Diseases (ICD-10, 2011) and grouped into five categories ${ }^{3,11}$, namely, urinary tract diseases (N30-N39), breast diseases (N60-N64), inflammatory diseases of the female pelvic organs (N70-N77), 
TABLE 1. CHARACTERIZATION AND TYPES OF GYNECOLOGICAL DIAGNOSES IN CLIMACTERIC WOMEN TREATED AT THE WOMEN'S HEALTH OUTPATIENT CLINIC IN THE UNIVERSITY HOSPITAL OF THE UNIVERSITY OF SÃO PAULO (ASM/HU/USP).

\begin{tabular}{|c|c|c|}
\hline Characteristics & $\mathrm{N}$ & $\%$ \\
\hline \multicolumn{3}{|l|}{ Age (years) } \\
\hline $40-44$ & 70 & 28.92 \\
\hline $45-54$ & 99 & 40.91 \\
\hline $55-64$ & 68 & 28.10 \\
\hline 65 & 5 & 2.06 \\
\hline \multicolumn{3}{|l|}{ Race } \\
\hline White & 142 & 62.83 \\
\hline Not white & 84 & 37.17 \\
\hline \multicolumn{3}{|l|}{ Employment } \\
\hline No & 100 & 58.14 \\
\hline Yes & 72 & 41.86 \\
\hline \multicolumn{3}{|l|}{ Multimorbidity } \\
\hline No & 83 & 35.78 \\
\hline Yes & 149 & 64.22 \\
\hline \multicolumn{3}{|l|}{ Alcohol consumption } \\
\hline No & 182 & 95.79 \\
\hline Yes & 8 & 4.21 \\
\hline \multicolumn{3}{|l|}{ Menarche (years) } \\
\hline $8-12$ & 95 & 39.09 \\
\hline $13-16$ & 100 & 41.56 \\
\hline$>16$ & 14 & 5.76 \\
\hline \multicolumn{3}{|l|}{ Menopause } \\
\hline No & 146 & 60.33 \\
\hline Yes & 96 & 39.67 \\
\hline \multicolumn{3}{|l|}{ Natural age at menopause (years) } \\
\hline$<40$ & 9 & 9.47 \\
\hline $40-45$ & 20 & 21.05 \\
\hline $46-54$ & 51 & 53.68 \\
\hline$>55$ & 15 & 15.79 \\
\hline \multicolumn{3}{|l|}{ Smoker } \\
\hline No & 154 & 75.12 \\
\hline Yes & 51 & 24.88 \\
\hline \multicolumn{3}{|l|}{ Parity } \\
\hline Nulliparous & 21 & 8.64 \\
\hline $1-2$ pregnancies & 92 & 37.86 \\
\hline 3 or more pregnancies & 129 & 53.50 \\
\hline \multicolumn{3}{|l|}{ Active sex life } \\
\hline No & 64 & 32.49 \\
\hline Yes & 133 & 67.51 \\
\hline \multicolumn{3}{|l|}{ Types of diagnoses } \\
\hline Urinary tract diseases (N30-N39) & 59 & 24.28 \\
\hline Breast diseases (N60-N64) & 9 & 3.70 \\
\hline $\begin{array}{l}\text { Inflammatory diseases of the female pelvic } \\
\text { organs (N70-N77) }\end{array}$ & 16 & 6.58 \\
\hline $\begin{array}{l}\text { Noninflammatory disorders of the female } \\
\text { genital tract (N80-N99) }\end{array}$ & 181 & 74.49 \\
\hline $\begin{array}{l}\text { General examination, contraception, and } \\
\text { procreation }(\mathrm{ZOO}-31)\end{array}$ & 9 & 3.70 \\
\hline
\end{tabular}

noninflammatory disorders of the female genital tract (N80-N99), and general examination and investigation of patients without complaints (ZOO-31). The grouping was based on clinical symptoms and similar diagnostic evaluations. When a patient had two or more diagnoses, each one was described separately. The exclusion criteria were pregnancy, childbirth, puerperium, ectopic pregnancy, and cancer, as well as incomplete information. Oncological diagnoses were not referred to the outpatient clinic but to oncological treatment services in the healthcare network.

Healthcare services were characterized according to the type of assistance provided and the complexity as primary sector or low complexity (basic healthcare clinics, teaching healthcare centers, women's outpatient clinics), secondary sector or medium complexity (the university hospital and other medium-complexity hospitals and surgical specialty clinics), and tertiary sector or high complexity (high-complexity hospitals and oncological support hospitals). The flow of the healthcare service distribution started at the referral and counter-referral services, i.e., the place of origin and the place where the patient received the treatment or returned to the place of origin.

\section{Ethical aspects}

This research was analyzed and approved by the Ethics Committee of the University of São Paulo School of Medicine under opinion No. 228/13.

\section{Statistical analysis}

Study variables were grouped by absolute and relative frequency and odds ratio, as described in tables. The odds ratio was estimated using logistic regression. Stata ${ }^{\circledast}$ software (StataCorp, LC) version 11.0 was used for statistical analysis, and the significance level was $5 \%$.

\section{RESULTS}

A total of 428 women were observed and registered at the outpatient clinic in the University of ASM - HU/USP during the study period, with 242 climacteric women referred from the basic healthcare clinics (UBS) of Jardim São Jorge $(46.28 \%, \mathrm{n}=112)$, Jardim Boa Vista $(14.87 \%, \mathrm{n}=36)$, Vila Dalva $(10.33 \%, \mathrm{n}=25)$, Jardim Jaqueline $(7.85 \%, \mathrm{n}=19)$, Butantã $(7.02 \%, \mathrm{n}$ $=17)$, Jardim d'Abril $(4.96 \%, \mathrm{n}=12)$, and Vila Sônia $(0.41 \%, \mathrm{n}=1)$, as well as the staff at the University Hospital and other health centers $(8.26 \%, \mathrm{n}=20)$. 
Of the 242 cases, only $54.3 \%$ were low-complexity cases of possible resolution in the referred outpatient clinic (clinical management), $42 \%$ required other interventions (outpatient or hospital) and were referred to medium-complexity services, and 3.7\% were referred to high-complexity services (Figure 1).

The main gynecological and non-oncological diagnoses found in patients treated at 'the University of ASM - HU/USP were noninflammatory disorders of the female genital tract (N80-N99), 74.49\% (181); urinary tract diseases (N30-N39), 24.28\% (59); inflammatory diseases of the female pelvic organs (N70-N77), 6.58\% (16); breast diseases (N60-N64), 3.70\% (9); and general examination, contraception, and procreation (Z00-31), 3.70\% (9).

As shown in Table 2, of the sociodemographic factors and clinical history, smoking $(\mathrm{OR}=2.27,95 \% \mathrm{CI}$ $1.05-4.89 ; p=0.035$ ) was associated with the referral of climacteric women to higher-complexity services.

The distribution of non-oncological diagnoses in climacteric women (Table 2) shows that the chance of a woman being referred to medium- and high-complexity services was 2 times higher in cases of breast diseases, 2.35 times higher in cases of noninflammatory disorders of the female genital tract, and 3 times higher in cases of inflammatory diseases of the pelvic organs, with no statistically significant difference.

\section{DISCUSSION}

Healthcare service evaluation studies characterize the assisted population, identify the referral flow of patients at different levels of healthcare services, and improve the quality of care.

Clinical, sociodemographic, and gynecological

FIGURE 1. DISTRIBUTION OF RECORDS OF WOMEN RESPONSIVE TO PRIMARY CARE AND THOSE REQUIRING TERTIARY CARE.

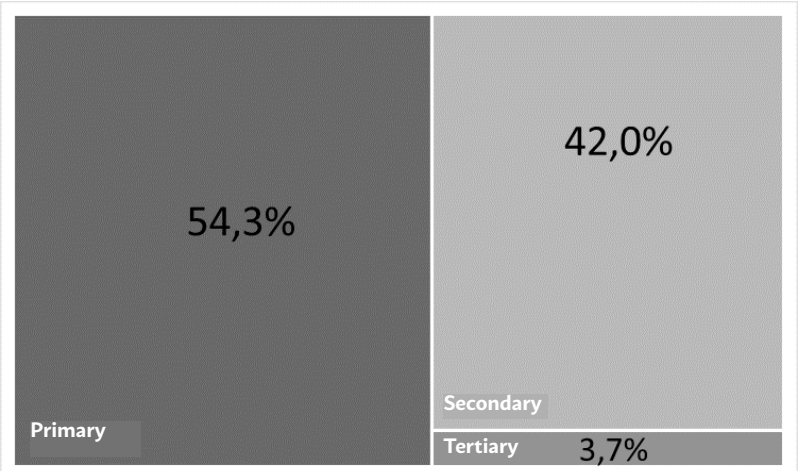

and obstetric characteristics of patients treated at the Women's Outpatient Health Clinic are similar to those found ${ }^{3,12-14}$ in São Paulo and in the Southern Brasil regions. Our results describe climacteric women in transition to late menopause and in the first post-menopause years, with at least two or more associated clinical diseases (hypertension, diabetes, or hypothyroidism), who were multiparous, unemployed, and smokers.

The main healthcare diagnoses in gynecology found in this study were noninflammatory disorders of the female genital tract and diseases of the urinary tract, reflecting the healthcare reality of climacteric women in basic health clinics ${ }^{15,16}$.

Noninflammatory disorders of the female genital tract, including abnormal uterine bleeding, have a prevalence of $40-60 \%$ in the reproductive period, which may worsen in the late reproductive period due to progressive ovarian ${ }^{17,18}$ and physiological dysfunction. Symptoms related to changes in the menstrual cycle can lead to anemia ${ }^{19}$, which implies morbidity and mortality ${ }^{20}$. Furthermore, these disorders can affect women's health and cause imbalances in their sexual activity ${ }^{15,17,18}$.

Adequate clinical management in primary care becomes relevant to avoid worsening women's health ${ }^{1,7,21}$. In addition, noninflammatory disorders of the female genital tract are the most common non-oncological diagnoses in tertiary care, showing an important financial impact on healthcare systems ${ }^{3,22}$. Thus, clinical outpatient control of these patients through the incorporation of drug therapy (such as levonorgestrel-releasing intrauterine devices and others not yet available in the market, such as progesterone receptor analogues) can be performed in low-complexity services, which is essential for avoiding high costs and reducing morbidity.

Demands related to urogenital dysfunction are common and have negative effects on different aspects of a woman's lives. In this study sample, these demands were assisted at the primary and secondary care levels ${ }^{16,22}$. Health professionals working with women's health in low-complexity settings should be aware and trained in assisting women with non-oncological gynecological diagnoses so that these women can receive adequate clinical management, thereby improving their reproductive and sexual health ${ }^{7,13}$.

Inflammatory diseases of the female pelvic organs, breast disorders, general physical examination, contraception, and reproduction were also reported 
TABLE 2. FACTORS ASSOCIATED WITH THE REFERRAL OF CLIMACTERIC WOMEN TO MEDIUM- AND HIGHCOMPLEXITY SERVICES AT THE WOMEN'S HEALTH OUTPATIENT CLINIC IN THE UNIVERSITY HOSPITAL OF THE UNIVERSITY OF SÃO PAULO (ASM/HU/USP).

\begin{tabular}{|c|c|c|c|}
\hline Characteristics & Odds & OR $(95 \% \mathrm{Cl})$ & $p^{*}$ \\
\hline \multicolumn{4}{|l|}{ Age (years) } \\
\hline $40-44$ & 1.80 & ref. & ref. \\
\hline $45-54$ & 1.56 & $0.86(0.46-1.63)$ & 0.664 \\
\hline $55-64$ & 3.85 & $2.14(0.99-4.60)$ & 0.051 \\
\hline 65 & 1.50 & $0.83(0.13-5.32)$ & 0.847 \\
\hline \multicolumn{4}{|l|}{ Race } \\
\hline White & 2.02 & ref. & ref. \\
\hline Not white & 2.00 & $0.98(0.55-1.75)$ & 0.971 \\
\hline \multicolumn{4}{|l|}{ Employment } \\
\hline No & 2.70 & ref. & ref. \\
\hline Yes & 2.00 & $0.74(0.38-1.43)$ & 0.370 \\
\hline \multicolumn{4}{|l|}{ Multimorbidity } \\
\hline No & 1.67 & ref. & ref. \\
\hline Yes & 2.31 & $1.37(0.78-2.42)$ & 0.267 \\
\hline \multicolumn{4}{|c|}{ Alcohol consumption } \\
\hline No & 2.08 & ref. & ref. \\
\hline Yes & 1.66 & $0.79(0.18-3.45)$ & 0.765 \\
\hline \multicolumn{4}{|l|}{ Menarche (years) } \\
\hline $8-12$ & 1.50 & ref. & ref. \\
\hline $13-16$ & 2.15 & $1.43(0.79-2.58)$ & 0.225 \\
\hline$>16$ & 3.66 & $2.44(0.63-9.34)$ & 0.191 \\
\hline \multicolumn{4}{|l|}{ Menopause } \\
\hline No & 1.77 & ref. & ref. \\
\hline Yes & 2.55 & $1.44(0.82-251)$ & 0.199 \\
\hline \multicolumn{4}{|c|}{$\begin{array}{l}\text { Natural age at menopause } \\
\text { (years) }\end{array}$} \\
\hline$>40$ & 3.50 & ref. & ref. \\
\hline $40-45$ & 4.00 & $1.14(0.16-7.76)$ & 0.891 \\
\hline $46-54$ & 2.40 & $0.68(0.12-3.69)$ & 0.660 \\
\hline $55-65$ & 1.50 & $0.42(0.06-2.81)$ & 0.377 \\
\hline
\end{tabular}

\begin{tabular}{|c|c|c|c|}
\hline Characteristics & Odds & OR $(95 \% \mathrm{Cl})$ & $\mathrm{p}^{*}$ \\
\hline \multicolumn{4}{|l|}{ Smoker } \\
\hline No & 1.80 & ref. & ref. \\
\hline Yes & 4.10 & $2.27(1.05-4.89)$ & 0.035 \\
\hline \multicolumn{4}{|l|}{ Parity } \\
\hline Nulliparous & 1.33 & ref. & ref. \\
\hline 1-2 pregnancies & 2.17 & $1.62(0.61-4.29)$ & 0.324 \\
\hline 3 or more pregnancies & 2.09 & $1.57(0.61-4.02)$ & 0.346 \\
\hline \multicolumn{4}{|l|}{ Active sex life } \\
\hline No & 2.20 & ref. & ref. \\
\hline Yes & 2.02 & $0.91(0.48-1.74)$ & 0.797 \\
\hline \multicolumn{4}{|l|}{ Types of diagnoses } \\
\hline \multicolumn{4}{|l|}{$\begin{array}{l}\text { Urinary tract diseases } \\
\text { (N30-N39) }\end{array}$} \\
\hline No & 1.09 & ref. & ref. \\
\hline Yes & 1.56 & $0.70(0.38-1.29)$ & 0.256 \\
\hline \multicolumn{4}{|l|}{$\begin{array}{l}\text { Breast Diseases (N60- } \\
\text { N64) }\end{array}$} \\
\hline No & 1.96 & ref. & ref. \\
\hline Yes & 2.00 & $0.98(0.23-4.02)$ & 0.979 \\
\hline \multicolumn{4}{|c|}{$\begin{array}{l}\text { Inflammatory diseases of female } \\
\text { pelvic organs (N70-N77) }\end{array}$} \\
\hline No & 4.53 & ref. & ref. \\
\hline Yes & 3.00 & $1.51(0.47-4.83)$ & 0.488 \\
\hline \multicolumn{4}{|c|}{$\begin{array}{l}\text { Non-inflammatory disorders of the } \\
\text { female genital tract (N80-N99) }\end{array}$} \\
\hline No & 4.00 & ref. & ref. \\
\hline Yes & 2.35 & $1.69(0.93-3.08)$ & 0.082 \\
\hline \multicolumn{4}{|c|}{$\begin{array}{l}\text { General examination, contraception, } \\
\text { and procreation (ZOO-31) }\end{array}$} \\
\hline No & 0.75 & ref. & ref. \\
\hline Yes & 1.25 & $0.60(0.15-2.30)$ & 0.458 \\
\hline
\end{tabular}

OR: odds ratio; ref: reference category; ${ }^{\star}$ logistic regression; ${ }^{* \star}$ Absence of this diagnosis as reference.

by patients in this study, which corresponds with demands related to the late reproductive period and to sexual activity ${ }^{5,13}$.

Benign breast diseases are more likely to be diagnosed during the nonreproductive period. However, it is important to highlight that only clinical complaints of benign breast disorders were evaluated in this outpatient clinic, and clinical management was performed mainly in medium- and high-complexity facilities. This may corroborate the specificity of this entity and emphasize the importance of specialized physicians in healthcare ${ }^{23}$.

Patient survey was conducted in a training program with emphasis on women's health and the main areas of investment were identified, such as health education for professionals and encouragement of multidisciplinary work $\mathrm{w}^{3-5}$. Thus, this study reinforces the importance of training health professionals in basic healthcare clinics on the climacteric period and on the clinical management of abnormal uterine bleeding and urogenital dysfunction.

The distribution of healthcare service utilization was considered appropriate, according to the literature in countries using hierarchical healthcare levels and universal access, such as the United Kingdom and Canada ${ }^{24}$. The final referral of patients, mostly to the primary sector, is considered satisfactory and expected in a hierarchical health system. However, special attention should be given to the need to optimize services and referral flows at various healthcare system levels to improve healthcare quality, especially regarding women's health ${ }^{10,11}$. 
A Brazilian study on a medical audit of the prenatal care program in the Southern region of the country showed that the use of epidemiological methods to organize healthcare services is important for improving the quality of care ${ }^{25}$.

Descriptive and retrospective studies have their own limitations, especially considering the quality of sociodemographic information records, indeterminate racial classification in Brasil, and clinical data recorded with heterogeneous criteria.

Furthermore, the local demands and use of health services for women's care described in this study may not represent the demands in the Brazilian Unified Health System, because the analyzed outpatient clinic is accredited to a teaching and learning unit.

The novelty of this study lies in its correlation between the main diagnoses in climacteric women's health and the hierarchization of healthcare service levels, associating women's demands and healthcare needs at different healthcare levels. This should benefit the fields of health promotion and medical and interdisciplinary education, highlighting current issues in the daily life of climacteric women and in public health according to healthcare complexity levels.

\section{CONCLUSIONS}

Climacteric women aged over 55 years, postmenopausal women, and smokers were most frequently referred to medium- and high-complexity surgical facilities.

\section{Author's Contribution}

Isabel Cristina Esposito Sorpreso: concept, data curatorship, formal analysis, research, methodology, project management, software, supervision, validation, visualization, writing (original draft, review, and editing).

Francisco Winter dos Santos Figueiredo: formal analysis, methodology, software, Writing (original draft, review, and editing).

Adna Thaysa Marcial da Silva: data curatorship, methodology, software, writing (original draft, review, and editing).

Juliana Zangirolami-Raimundo: formal analysis, methodology, writing (original draft, review, and editing).

Bhárbara Karolline Rodrigues Silva: formal analysis, methodology, software, writing original draft.

Fernando Adami: formal analysis, methodology, software.

Lea Tami Suzuki Zuchelo: concept, data curatorship, formal analysis, methodology, software, writing (original draft, review, and editing).

Edmund Chada Baracat: concept, data curatorship, project management, supervision, writing (original draft, review, and editing).

José Maria Soares Júnior: formal analysis, methodology, project management, software, supervision, writing (original draft, -review, and editing).

Luiz Carlos de Abreu: project management, supervision, visualization.

\section{RESUMO}

INTRODUÇãO: A associação entre diagnósticos ginecológicos e sua distribuição nos setores de saúde proporciona benefícios no campo da promoção de saúde e na identificação de temas para educação continuada na assistência.

OBJETIVO: Identificar os diagnósticos em saúde e o fluxo de encaminhamento de mulheres no climatério.

MÉTODO: Trata-se de estudo transversal realizado no Ambulatório de Saúde da Mulher do Hospital Universitário da Universidade de São Paulo, de referência em ginecologia e de treinamento para residentes de Medicina de Família e Comunidade, entre 2017-2018. A casuística foi realizada a partir de 274 prontuários de mulheres atendidas e foram processados informações sociodemográficas e clínicas, diagnósticos ginecológicos e distribuição dos serviços de saúde (primário, secundário e terciário). O teste qui-quadrado e razão de chance foram utilizados para estatística.

RESULTADOS: O tabagismo (OR=2,27, IC95\% 1,05;4,89, $p=0,035)$ foi associado ao encaminhamento de mulheres no climatério para a maior complexidade. Em relação aos tipos de diagnóstico, a chance de serem encaminhadas para a média e alta complexidade foi de 135\% (OR=1,69, IC95\% 0,93;3,08) nos transtornos não inflamatórios do trato genital feminino, 200\% (OR=0,98, IC95\% 0,23;4,02) nas doenças da mama, 300\% (OR=1,51, IC95\% 0,47;4,83) nos transtornos inflamatórios do trato genital feminino, sem predomínio entre os diagnósticos.

CONCLUSÃo: As mulheres climatéricas e na pós-menopausa acima de 50 anos e tabagistas com diagnósticos de transtornos não inflamatórios do trato genital feminino e inflamatórios, bem como doenças da mama, foram as mais direcionadas para ambulatório cirúrgico na média e alta complexidade.

PALAVRAS-CHAVE: Serviços de saúde. Ginecologia. Saúde da mulher. Níveis de atenção à saúde. Sistemas de saúde. 


\section{REFERENCES}

1. Starfield B. Atenção primária: Equilíbrio entre necessidades de saúde, serviços e tecnologia. Brasília: Unesco, Ministério da Saúde; 2004.

2. Donabedian, A. Promoting quality through evaluating the process of patient care. Medical Care. 1968; 6(3):181-202.

3. Da Silva ATM, Menezes Cl, Santos EFS, Margarido PFR, Soares Junior JM, Baracat EC, et al. Referral gynecological ambulatory clinic: principal diagnosis and distribution in health services. BMC Women's Health. 2018; 18: 8.

4. Casas RS, Hallett LD, Rich CA, Gerber MR, Battaglia TA. Program directors' perceptions of resident education in women's health: A national survey. Women's Health (Larchmt). 2017; 26(2):133-40.

5. Foreman $\mathrm{H}$, Weber $\mathrm{L}$, Thacker HL. Update: A review of Women's Health Fellowships, their role in interdisciplinary health care, and the need for accreditation. J Women's Health (Larchmt). 2015; 24(5): 336-40.

6. Brasil. Ministério da Saúde. Secretaria de Atenção à Saúde. Departamento de Ações Programáticas Estratégicas. Política nacional de atenção integral à saúde da mulher: princípios e diretrizes. Brasília: Ministério da Saúde; 2004b.

7. Starfield B, Shi L, Macinko J. Contribution of primary care to health systems and health. Milbank Q. 2005; 83(3): 457-502.

8. Dall TM, Chakrabarti R, Storm MV, Elwell EC, Rayburn WF. Estimated demand for women's health services by 2020. J Women's Health (Larchmt). 2013; 22(7): 643-8

9. Gee RE, Rosenbaum S. The Affordable Care Act: an overview for obstetricians and gynecologists. Obstet Gynecol. 2012; 120(6): 1263-6.

10. Chang CP, Chou CL, Chou YC, Shao CC, Su IH, Chen TJ, Chou LF, Yu HC. The ecology of gynecological care for women. Int J Environ Res Public Health. 2014; 11(8): 7669-77.

11. Nicholson WK, Ellison SA, Grason H, Powe NR. Patterns of ambulatory care use for gynecologic conditions: A national study. Am J Obstet Gynecol. 2001; 184(4): 523-30

12. Roman EP, Ribeiro RR, Guerra-Júnior G, Barros-Filho AA. Antropometria maturação sexual e idade da menarca de acordo com o nível socioeconômico de meninas escolares de Cascavel (PR). Rev Assoc Med Bras. 2009; 55(3): $317-21$.

13. Fernandes MAS, Yamada EM, Sollero CA, Leme LCPaes. Distrito de saúde de origem e características sociodemográficas das mulheres atendidas em unidade secundária de referência do Sistema Unico de Saúde em Campinas.
Rev Ciênc Méd (Campinas). 2005; 14(4): 327-35.

14. Bagnoli VR, Fonseca AM, Arie WM, Das Neves EM, Azevedo RS, Sorpreso IC, Soares Júnior JM, Baracat EC. Metabolic disorder and obesity in 5027 Brazilian postmenopausal women. Gynecol Endocrinol. 2014; 30(10): 717-20.

15. Côté I, Jacobs P, Cumming DC. Work loss associated with increased menstrual loss in the United States. Obstet Gynecol. 2002; 100(4): 683-7.

16. Jha S. Moran P, Blackwell A, Greenham H. Integrated care pathways: The way forward for continence services? Eur J Obstet Gynecol Reprod Biol. 2007; 134(1): 120-5.

17. Côté I, Jacobs P, Cumming DC. Use of health services associated with increased menstrual loss in the United States. Am | Obstet Gynecol. 2003; 188(2): 343-8.

18. Shapley M, Jordan K, Croft PR. Abnormal bleeding patterns associated with menorrhagia in women in the community and in women presenting to primary care. Fam Pract. 2007; 24(6): 532-7.

19. Wang ET, Cirillo PM, Vittinghoff, E. Bibbins-Domingo K, Cohn BA, Cedars MI. Menstrual irregularity and cardiovascular mortality. | Clin Endocrinol Metab. 2011; 96(1): E114-8

20. Talbott EO. Premenstrual syndrome and increased blood pressure: a new risk factor for cardiovascular disease in women? J Women's Health (Larchmt). 2016; 25(11): 1083-4.

21. Macinko J, Harris MJ. Brasil's family health strategy - delivering community-based primary care in a universal health system. N Engl J Med. 2015; 372: 2177-81.

22. De Vries CJH, Wieringa-de Waard M, Vervoot CLG, Ankum WM, Blndels PJE. Abnormal vaginal bleeding in women of reproductive age: a descriptive study of initial management in general practice. BMC Women's Health. 2008; 8: 7 .

23. Worsham MJ, Abrams J, Raju U, Kapke A, Lu M, Cheng J, Mott D, Wolman $\mathrm{SR}$. Breast cancer incidence in a cohort of women with benign breast disease from a multiethnic, primary health care population. Breast J. 2007; 13(2): $115-21$.

24. Shi L. The impact of primary care: A focused review. Scientifica (Cairo). 2012; 2012: 432892

25. Dias-da-Costa JS, Madeira ACC, Luz RM, Britto MAP. Medical audit: prenatal care program 3in a health center in southern Brasil. Rev Saude Publica. 2000; 34(4): 329-36. 